\title{
CULTURA POPULAR E SENSIBILIDADE ROMÂNTICA: as danças dramáticas de Mário de Andrade
}

\section{Maria Laura Viveiros de Castro Cavalcanti}

Why have I sought my path with fervent care, if not to hope to bring my brothers there?

Goethe, Fausto.

Preâmbulo: Por que Mário de Andrade viu no Bumba não só "a mais exemplar" como também "a mais estranha" das danças dramáticas?

Mário de Andrade encharcou de folclore a cultura brasileira e emerge hoje como uma incontornável esfinge no percurso dos estudos das artes e das culturas populares. Seu estilo direto, permeado de arroubos expressivos, quase confessionais, dá-nos a imediata e perturbadora ilusão de compartilharmos com ele uma dimensão íntima de sub-

Artigo recebido em novembro/2002 Aprovado em setembro/2003 jetividade. ${ }^{1}$ Conforme a leitura se estende, começamos inadvertidamente a tratá-lo com a familiaridade de um conviva diário: Mário. Ao mesmo tempo, sua presença ideológica difusa e muito ativa marca o cenário de debates contemporâneos. Diversos temas, como é, muito especialmente, o caso do Bumba-meu-boi, emergem como que impregnados de Mário de Andrade. ${ }^{2}$

Sua presença insinuou-se com força cada vez maior ao longo de minha pesquisa sobre o BoiBumbá de Parintins (AM) que, iniciada em 1996, foi alargando horizontes, incluindo reflexões não só sobre a brincadeira do boi no Brasil, como também sobre a própria leitura e utilização antropológica contemporânea dos estudos de folclore. ${ }^{3}$ Surpreendeu-me, sobretudo, a forma ambivalente pela qual a forte influência de Mário de Andrade se impôs.

Em seu texto "As danças dramáticas do Brasil" (1982), escrito entre 1934 e 1944, Mário de Andrade tratou de conceituar essas danças, destacando o 
bumba-meu-boi como "a mais exemplar" e, também, como "a mais complexa, estranha, original de todas as nossas danças dramáticas”. Entretanto, na conclusão de seu périplo de estudos, nosso autor vaticinou, em feroz desalento, um triste destino para as danças que tanto o fascinaram: "Da maneira como as coisas vão indo, a sentença é de morte".

A vitalidade contemporânea da brincadeira do boi e de diversos folguedos populares contradiz, por si só e para nossa felicidade, esse oráculo. Assim é que, considerada sob seu ângulo mais concreto, como taxativa afirmação sobre o devir da cultura popular, a douta sentença se esvanece. Está certo que, sob o ângulo ideológico, a própria vitalidade atual dos folguedos populares poderia falar justamente do sucesso póstumo do combate de Mário de Andrade em prol da originalidade cultural do país. Entretanto, quando considerado sob essa perspectiva, o decreto de morte parece trazer consigo fortes conotações subjetivas, acentuando a nostalgia romântica, tão característica no trato das coisas populares, com a amargura e as decepções do autor com os rumos da política cultural de então. Ainda assim, ao longo de seu estudo das danças dramáticas, inquietações intelectuais instigantes, percepções conceituais sensíveis e argutas mantêm o calor de brasas vivas. Sob esse ângulo mais analítico, Mário de Andrade insiste em ressurgir das cinzas de sua assertiva fatal. ${ }^{4}$

Em um primeiro texto sobre o Bumbá de Parintins (Cavalcanti, 2000), sugerindo uma perspectiva estrutural, associei as transformações e as expansões do festival nas últimas décadas, responsáveis por sua singularidade amazônica, a uma matriz de sentido articulada em torno do tema da morte e ressurreição do boi. ${ }^{5}$ Em que pese a distância teórica existente entre a noção de mito evolucionista com que Mário de Andrade operava e a noção antropológica contemporânea, ${ }^{6}$ na idéia de uma "matriz de sentido" ressoa a concepção andradiana de um "núcleo" de sentido "mítico" a ordenar, por vezes, o agregado compósito das danças dramáticas. Além disso, a definição formal de Mário de Andrade para essas danças - uma seqüência dançada de cenas dramáticas, livremente articuladas a partir de um conjunto de personagens alusivos ao motivo central - permanece sucinta e eficaz para o entendimento do arcabouço formal dos espetáculos do Bumbá.
O assunto clamou por aprofundamento. Não haveria alguma relação mais interna entre o decreto de morte e a própria conceituação das danças dramáticas? Afinal, seria possível, ao mesmo tempo, recusar o vaticínio e manter aspectos da formulação conceitual? Como dar conta de minha própria ambivalência em relação ao autor? Como entender a idéia da "exemplaridade" cultural e nacionalizante do Bumba-meu-boi assumida tão acriticamente por tantos pesquisadores do assunto? Este texto é o resultado dessa busca.

\section{Mário de Andrade e os estudos de folclore}

O interesse expressivo e etnográfico de Mário de Andrade pelo folclore, bem como sua busca, via folclore, do acesso a uma arte e cultura que, sendo "modernas", seriam também, a um só tempo, "nacionais" e "universais" estão bem estabelecidos na bibliografia sobre o autor (Lopez, 1972; Mello e Souza, 1979; Moraes, 1978, 1992; Travassos, 1997).

Já em 1946, Florestan Fernandes assinalava a importância da abordagem do folclórico na obra de Mário de Andrade:

É preciso não esquecer que o folclore domina - e até certo ponto marca profundamente - sua atividade polimórfica de poeta, contista, romancista, crítico e ensaísta; e constitui também o seu campo predileto de pesquisas e estudos especializados. Por isso, quando se pretende analisar a sua contribuição ao folclore brasileiro, deve-se distinguir o que fez como literato do que realizou, digamos à sua revelia, como folclorista (1989, p. 150).

Em suas análises sobre o Modernismo, Moraes considerou Mário de Andrade o representante de uma "via de pesquisa, no sentido quase universitário da palavra" (1978, p. 93), demonstrando, com particular clareza, o lugar estratégico ocupado pela categoria "folclore" na proposta de nacionalismo cultural do autor.

Ora, a associação do folclore a uma "via de pesquisa" indica a apreensão, por parte de Mário de Andrade, de uma originalidade e autonomia 
nos fatos populares que não permitem sua simples redução à pura (ainda que sempre sofisticada) instrumentalização, seja ela ideológica ou artística. Tratava-se, entretanto, de um folclorista à revelia, num sem-querer querendo, ardentemente. Os sentimentos de Mário de Andrade com relação à pesquisa folclórica que indubitavelmente praticou eram, sem dúvida, contraditórios.

Em sua viagem ao nordeste, quando chegou a Natal (RN), em 15 de dezembro de 1928, sem conseguir "dormir de felicidade" e anotando correções importantes a serem feitas em seu Ensaio sobre música brasileira (1972 [1928]), Mário de Andrade defende-se do ímpeto estudioso confesso. Ironiza a aspiração dos estudos de folclore ao estatuto de ciência, e reconhece-se sobretudo um "coletor" a "fornecer documentação pra músico" (1976, pp. 231-232). Entretanto, como corrobora Travassos (2002), em meio a seus muitos propósitos, com suas reflexões, pesquisas e coletas, Mário de Andrade colaborou decisivamente para $\mathrm{O}$ desenvolvimento dos estudos de folclore no país. ${ }^{7}$

Sua pesquisa folclórica está certamente permeada de juízos de valor, pois Mário de Andrade projetou sobre o folclore interesses instrumentais e fortemente ideológicos. Porém, as descobertas do Brasil, ${ }^{8}$ que tanto o comoveram ou chatearam, alardearam em alto e bom som assuntos que alargaram horizontes de conhecimento e de sociabilidade: catopês, cateretês, cabocolinhos, Chico Antônio, Nau Catarineta... Tanta gente, tanta festa, tanto artista sem saber de ser: "Êh coisas de minha terra, passados e formas de agora/Êh ritmos de síncopa e cheiros lentos de sertão/Varando contracorrente o mato impenetrável do meu ser..."?

No solo híbrido de suas pesquisas, insinuam-se também vozes próprias e distintas da sua - vozes "do povo" - captadas pelo ângulo mais universalista e humanista de sua aproximação. Por tudo isso, Mário de Andrade ergue-se como um dos expoentes de uma área de estudos que se define não apenas pelo interesse intelectual pelos fatos estudados, mas também, muito especialmente, por uma peculiar atitude existencial. De seus primórdios até nossos dias, os estudos de folclore trazem embutida a notável capacidade de provocar entusiasmo, e mesmo encantamento. Mesmo quando fortemente acadêmico, o in- teresse pelo "folclore" traz consigo sempre um quê de desejo de libertação social, do prazer de transpor os limites de uma sociabilidade de classe, e de experimentar com isso o universal, uma humanidade em comum vivida junto com a gente do povo. ${ }^{10}$ Assim, não é apenas por buscar e produzir conhecimento sobre o povo, mas também por comover-se com esse tipo de contato humano que Mário de Andrade pode ser considerado um folclorista.

Esse encantamento, baseado na empatia, na capacidade de transpor-se para o lugar do outro e perceber, desse modo ficcional, o mundo sob novo ângulo, está presente em toda a tradição etnográfica decisiva para a constituição da perspectiva antropológica (Stocking, 1989; Zengotita, 1989; Duarte, 2003). Quando o assunto é folclore, o envolvimento de Mário de Andrade na tradição filosófica romântica é evidente. O folclore é, na arquitetura de sua obra, um canal privilegiado de religação com um mundo que aspira à totalidade. ${ }^{11}$

Aspiração sempre acompanhada de dolorosa e irremediável nostalgia: a totalidade almejada está perdida, ou a ponto de perder-se inexoravelmente, no mundo moderno. ${ }^{12}$ Os estudos de folclore são certamente, como já sugeriu Gonçalves, um dos lugares privilegiados de construção e de manifestação da "retórica da perda". Retórica que, como assinalou o autor, repousa sobre forte tensão: expulsa-se da totalidade construída imaginariamente - o "folclore brasileiro", por exemplo qualquer princípio de conflito, incoerência ou fragmentação. Isso posto, toda inconsistência ou problema surge nos quadros do pensamento sob a falsa aparência de um ataque externo (Gonçalves, 1997, p. 24).

Abordando a dimensão etnográfica e artística na obra de Mário de Andrade, Travassos observou também a presença de tensão de outra natureza, cunhada como "paradoxo do primitivismo". Essa noção sintetizaria a atitude intelectual, característica de certos movimentos artísticos do século XX que equacionaram a relação entre o "eu civilizado" e o "outro primitivo" por meio de um jogo de ausência e presença de qualidades culturais. Segundo a autora, Mário de Andrade estaria "entre os melhores representantes do paradoxo, para os brasileiros" (1997, p. 7). ${ }^{13}$ 
De fato, Mário de Andrade propôs e experimentou o encontro com a cultura popular de modo fortemente ambivalente. Numa variação do evolucionismo, a cultura popular apresenta-se em sua obra como valorização do primitivo, num confronto entre identidade e alteridade por meio de grupos humanos distintos. Acrescenta-se ainda, bem ao gosto romântico, a idéia de que a força nutriz da originalidade cultural brasileira está nas criações artísticas populares (Cavalcanti et al., 1992). O folclore é considerado, então, uma espécie de muiraquitã nacional, o amuleto da boa sorte sempre ameaçado pelo risco da perda. Pois, se é verdade que as qualidades perdidas e procuradas pelo "euartista-civilizado" se encontram no "outro-povo-primitivo”, esse encontro tão almejado, ao se realizar, produz sobretudo um terrível aguçamento do sentimento de perda. As qualidades observadas no povo vêem-se imediatamente mais ameaçadas do que nunca por tudo o que representa aquele mesmo que as reencontra e valoriza, desejoso de transpô-las para si. A construção do terceiro termo resultante desse encontro, uma nova arte brasileira como queria Mário de Andrade, traz consigo o mal-estar de uma fissura que não se aquieta nem com as mais ardentes descobertas da sensibilidade e do talento expressivo da gente do povo. A ligadura é incapaz de ser retida e parece sempre novamente prestes a se romper: "da maneira como as coisas vão indo a sentença é de morte!”.

\section{Mário de Andrade e o Bumba-meu-boi}

Em ensaio magistral sobre o romance $\mathrm{Macu}$ naima, Mello e Souza falou de sua tentativa de analisar "o grande dilaceramento que se projeta em todos os níveis da narrativa" (1979, p. 56); do "conhecimento da fissura profunda que fere todos os setores da reflexão de Mário de Andrade [...]" (Idem, p. 60); e do debate sobre a identidade brasileira que "nunca mais abandonará a reflexão atormentada do escritor" (Idem, p. 63). Segundo a autora, embora fraturado entre tensões e contradições, o pensamento de Mário de Andrade tem caráter unitário. Também Sandroni, ao comentar a poligrafia de Mário de Andrade, enfatiza a unida- de da obra. O célebre alexandrino "eu sou trezentos, sou trezentos e cinqüenta”, nos lembra esse autor, não exclui ou contradiz seu complemento menos conhecido - "Mas um dia afinal eu toparei comigo" (1988, p. 12). Vale a pena lembrar, com Anatol Rosenfeld (1973), os belos versos que seguem, concluindo a última estrofe desse poema: "Tenhamos paciência, andorinhas curtas/Só o esquecimento é que condensa/E então minha alma servirá de abrigo". ${ }^{14}$

Ora, a etimologia da palavra poligrafia indica sentidos recobertos. É não só a "obra de assuntos diversos", e a "qualidade de escrever de diversas maneiras", ou ainda "cifradamente", como também a "arte de decifrar esse tipo de escrita" (Houaiss, 2001). Todos poligrafamos quando pesquisamos Mário de Andrade. Sua obra apresentase como um vasto sistema fragmentário, em que nos enredamos na busca de laços e nexos de sentido, atendendo certamente a apelos do autor. ${ }^{15}$

Ora, entre os muitos níveis pelos quais o pensamento de Mário de Andrade se desloca, há elementos decisivos e recorrentes a estabelecerem interconexões de sentido: o "bumba-meu-boi" é nitidamente um deles. Moraes $(1978,1992)$ analisou o encadeamento de significados propiciado pela categoria folclore na complexa arquitetura do nacionalismo cultural andradiano. Lopez (1972, 2002) chamou atenção para a posição especial ocupada pelo bumba-meu-boi nesse contexto e examinou a presença do boi como símbolo na poesia de Mário de Andrade. Mello e Souza (1979), por sua vez, defendeu exemplarmente o papel de modelo de composição e criação artísticas ocupado pelo bumba-meu-boi na própria criação literária do modernismo andradiano. ${ }^{16}$

José Guilherme Merquior, resenhando o livro de Mello e Souza - "grande pequeno estudo" (1981, p. 267) - acentuou o pessimismo da leitura proposta baseado na iluminação da articulação dos dois eixos sintagmáticos condutores da narrativa de Macunaíma: não se trata só do herói que perde e recobra seu amuleto mágico, mas também, e sobretudo, do anti-herói que termina, finalmente, perdendo seu amuleto por conta de uma escolha funesta. "Em última análise, a rapsódia andradiana é um romance arturiano que levou 
uma tremenda injeção de ambivalência”, nos diz Merquior (Idem, p. 265).

A resenha ilumina, entretanto, outro aspecto fundamental da interpretação de Mello e Souza que vale ressaltar: a importância da forma estética na solução da busca nacionalista de nosso autor. ${ }^{17}$ Haveria aqui, um "otimismo da forma": o modelo compositivo do romance é o da música popular, que é também o das formas européias da suíte e da variação. A positividade nacionalista do projeto de Mário de Andrade - "nacionalismo de modulação", de qualidade estética "excepcionalmente inclusiva" (Idem, p. 266) - repousaria, então, na solução formal da expressão, e não na leitura ufanista do conteúdo do romance, de um pessimismo próximo ao trágico como demonstrou Mello e Souza. Em Macunaíma, nos diz Merquior, na composição do personagem como anti-herói, "malazarte amoral sem grei nem lei”, como na ópera, o melos deglutiria o ethos, revelando uma sociedade invertebrada "não uma sociedade sem classes, mas uma sociedade ainda sem dinâmica de classes, que começava a viver a modernização 'sofrendo-a' em vez de assumi-la"(Idem, p. 268). ${ }^{18}$

Volto ao nosso ponto, lembrando que o modelo da composição narrativa de Macunaíma não é simplesmente uma melodia mas, mais exatamente, um bailado popular: a "dança dramática" do bumba-meu-boi. Mello e Souza sugeriu a existência de afinidades estruturais entre o romance Macunaíma e "o bailado popular que melhor representava a nacionalidade" e demonstrou com maestria o anti-heroísmo de Macunaíma. Se assim o é, vale a pena problematizar também o ufanismo residual que permanece implícito nessa visão do folguedo do boi. Afinal, Mário de Andrade viu o bumba não só como a mais "exemplar", mas também a mais "estranha" das danças.

Com esse propósito, examino as formulações conceituais contidas em "As danças dramáticas do Brasil". A apreensão da complexidade de valores, dos impasses conceituais e da riqueza de percepções embutida na noção de danças dramáticas talvez possa contribuir para relativizar aspectos importantes da compreensão contemporânea do bumba-meu-boi. Talvez possa contribuir também para a integração desse aspecto da reflexão de Mário de Andrade às análises do conjunto de sua obra.

\section{As danças dramáticas do Brasil}

\author{
Quem dirá que não vivo satisfeito! Eu danço! [...] \\ Dança do berço: Sim e Não \\ Dança do berço: Não e $\operatorname{Sim}^{19}$
}

\section{Os textos e algum contexto}

Os estudos de Mário de Andrade sobre o folclore brasileiro situam-se num entrecruzamento de diferentes motivações. Neles se entrelaçam seu desejo de conhecimento de formas artísticas e expressivas próprias (ou seja, "populares", diversas daquelas praticadas e vividas pela elite artística brasileira ou paulistana da época); a experimentação amadorística da idéia de etnografia como experiência de contato direto com a gente do povo; a busca de processos criativos populares para utilização expressiva na composição de sua própria arte; e, finalmente, a utilização ideológica da idéia de folclore na busca de um novo nacionalismo cultural. Seus escritos sobre o assunto sobrepõem essas distintas camadas de interesse, imbricadas umas na outras sempre de modo especialmente tenso.

A publicação póstuma dos três tomos das "Danças dramáticas do Brasil" (doravante DDB) foi cuidadosamente organizada por Oneida Alvarenga (1982). O farto material coletado, acrescido de muitas notas e comentários, é precedido pelo ensaio do mesmo nome (doravante DD) que constitui aqui a referência de nossas indagações. Pela amplitude do impulso sistematizador e conceitual, esse texto ocupa lugar importante na caracterização de Mário de Andrade como um estudioso do folclore brasileiro. O corpo do texto, datado de 1934, sofreu revisões e significativos acréscimos até a publicação, em 1944, no VI Boletim LatinoAmericano de Música, sendo essa a versão publicada na coletânea sobre o tema. Alvarenga (1982, p. 21) assinala o fato de ser esse o único trabalho do autor sobre os bailados populares a apresentar uma "forma positivamente definitiva". O texto acompanhou, portanto, a vida do autor por um período de dez anos. O longo período de elaboração e o fato de tê-lo publicado em vida o tor- 
nam especialmente revelador da trajetória de estudos do autor.

Em sua origem, como indica Telê Porto Lopez (1972), a primeira versão das DD, escrita em 1934, corresponderia à expressão do amadurecimento do interesse pelo "folclore em si". A redação de Macunaíma (primeiro esboço em 1926/1927 e publicação em meados de 1928), na esteira dos poemas do Clã do Jaboti (1926), é vista pela autora como o início de uma fase em que o desejo do estudioso foi ganhando forma mais definida. ${ }^{20}$ Esse mesmo desejo teria movido as viagens ao Norte e ao Nordeste que, realizadas entre 1927 e 1929, foram postumamente publicadas em "O turista aprendiz" (Andrade, 1976). O início da redação das DD imbricar-se-ia, assim, com o impulso criativo que, iniciado em 1926, desaguaria também no aproveitamento literário da experiência das viagens.

Vale a pena examinar de mais perto a relação existente entre o material que compõe essas duas obras póstumas - "As danças dramáticas do Brasil" e "O turista aprendiz". Este último livro, organizado por Telê Porto Ancona Lopez, reúne sob o mesmo título dois projetos distintos embora interligados de Mário de Andrade. Como assinala a pesquisadora (Andrade, 1976, p. 89), o primeiro projeto foi batizado com esse nome pelo próprio autor. Em seu "mais advertência que prefácio" (Idem, p. 49), o autor nos esclarece que esses textos, escritos em cadernos e papéis soltos durante a viagem ao Norte do país, realizada entre 7 de maio e 15 de agosto de 1927, foram reunidos em 1943, visando à publicação. A pesquisadora, por sua vez, nos lembra que a época de decorrência não é, nesse caso, a mesma da redação, pois o escritor já maduro teria reescrito, em 1942, a experiência de 1927 (Idem, p. 39). Apesar do "cheiro de modernismo envelhecido" que o conjunto lhe trazia, Mário de Andrade almejava publicar essas memórias de um antiviajante "viajando sempre machucado, alarmado, incompleto, sempre inventando malquisto do ambiente estranho que percorre".

Porém, se viajar lhe trazia um forte sentimento de desajuste e inadaptação, era também experiência de contato e mesmo de revelações. Ao reler suas antigas notas, "sensações tão próxi- mas e intensas" teriam obrigado nosso autor a preservá-las. "Paciência..." - nos diz ele - acrescendo reticências irônicas a seu legado. Conhecemos assim sua primeira viagem por meio de um elaboradíssimo diário, cheio de desabafos e de tiradas literárias lapidadas por uma sensibilidade brincalhona e irônica, mesmo quando triste. Mário de Andrade quer falar de si, estabelecendo uma subjetividade que sofre e sente. Expressá-la é um prazer estético quase masoquista:

\footnotetext{
Não fui feito pra viajar, bolas! Estou sorrindo, mas por dentro de mim vai um arrependimento assombrado, cor de incesto. Entro na cabina, agora é tarde, já parti, nem posso me arrepender. Um vazio compacto dentro de mim. Sento em mim" (Idem, p. 51).
}

Lopez qualifica esse primeiro relato como "discurso propriamente literário, artisticamente trabalhado"(Idem, p. 39).

A pesquisadora observa, entretanto, já nesse primeiro diário a presença do interesse pelas "danças dramáticas". Há o caso nítido da ciranda com o episódio da morte e ressurreição do Carão, ${ }^{21}$ encontrada por feliz acaso e apressadamente registrada em 12 de junho (Idem, p. 97) no Alto Solimões, igarapé a dentro, num lugarejo chamado Caiçara. No retorno de Mário de Andrade a São Paulo, essa mesma ciranda seria objeto da primeira crônica (8/12/1927) do novo crítico do Diário Nacional. ${ }^{22}$ Essa crônica revela, de modo muito característico, o entrelaçamento do gosto do autor pela descrição etnográfica com a busca estética interessada cheia de juízos valorativos e permite algumas valiosas observações. Antes de mais nada, a expressão "dança dramática" está ausente. A ciranda é aqui apenas uma "festa popular", um "reisado" sem muita vitalidade dramática, cujo enredo era "vago e sem continuidade" (Idem, pp. 335-336), ou, mais ainda, "uma barafunda", não possuindo o "nexo e a legitimidade dramática do Boi-Bumbá”. A observação revela, com todas as letras, a preferência de Mário de Andrade pelo folguedo do Boi como já plenamente estabelecida em 1927.

Assim é que, apesar de enxergar no episódio da morte e ressurreição do Carão, a parte mais 
viva da festa, Mário de Andrade achou tudo muito sem graça:

\begin{abstract}
Afinal essa trapalhada dramática não passa duma brincadeira de crianças a que gente adulta mais primitiva deu uma função interessada mais característica e perceptível, macaqueando o amor, a religião, a caça e os animais tabus. Nem a dança vale nada, monótona, sem originalidade, primitiva, muito parecida com as danças indígenas que Martius e Léry descreveram. O que vale mesmo é a música (Idem, p. 336 ). ${ }^{23}$
\end{abstract}

A série de 1928-1929 responde a uma outra concepção de viagem, visivelmente comprometida com um relato mais objetivo de fatos. Como nos diz Lopez (Idem, p. 41): "trata-se do diário com o imediato endereço jornalístico”. Mário de Andrade viajava, então, como correspondente do Diário Nacional, tendo planejado coletas e estudos em estreito contato com Camara Cascudo. ${ }^{24} \mathrm{O}$ texto é uma coletânea das setenta crônicas que, escritas durante a sua permanência no Nordeste, entre 27 de novembro de 1928 e 5 de fevereiro de 1929, foram publicadas no Diário Nacional, na série "O turista aprendiz", entre 14 de dezembro de 1928 e 29 de março de 1929.

A relação entre esse segundo "diário" e as DD é especialmente orgânica. Grande parte da documentação relativa a melodias, coreografias e artes relatadas nessas crônicas compõe a coleta publicada nos três tomos de "As Danças dramáticas do Brasil". ${ }^{25}$ Segundo Lopez, o retorno dessa segunda viagem teria inaugurado intensos estudos, visando a compreender as danças registradas. Mário de Andrade teria se dedicado, com o afinco característico, ao estudo da tríade de antropólogos evolucionistas (Tylor, Frazer e Lévy-Bruhl). ${ }^{26}$ Em meio a esse projeto de estudos, inicia-se a redação do texto (DD) que nos interessa especialmente.

O Instituto de Estudos Brasileiros - IEB da USP, guardião do arquivo Mário de Andrade, dispõe das versões anteriores àquela publicada. A versão publicada por Oneida Alvarenga nos servirá de referência básica, muito embora a consideração do conjunto das versões permita precisar e esclarecer pontos relevantes. ${ }^{27}$

$\mathrm{O}$ argumento e a direção geral do texto es- tão já claramente definidos desde a primeira versão do texto. Essa versão, datada de 1934, compõe-se de 27 páginas e termina no trecho correspondente ao da penúltima página da versão publicada, com a palavra "Rio Grande do Norte" (Andrade, 1982, p. 69). Segue-se a esse final datilografado a seguinte anotação feita a lápis pelo autor: "decadência atual das danças dramáticas". O tema da decadência seria desenvolvido então na "segunda versão" do texto, datada do mesmo ano. Com acréscimos que pouco alteraram seu conteúdo, esse trecho corresponde ao longo e último parágrafo da versão publicada (1944). A terceira versão, datada ainda de 1934, corresponde à datilografia das revisões empreendidas pelo autor na versão anterior. $O$ processo de confecção do texto interrompe-se e, aparentemente, será retomado apenas dez anos mais tarde, em 1944, com a revisão dessa terceira versão e, finalmente, com a redação e a revisão da quarta versão que corresponde ao texto publicado.

A idéia da degradação das danças está, portanto, presente desde o momento inicial do texto, integrando a abordagem do assunto. Ela se torna, apenas, mais desesperançada entre a versão finalizada em 1934 (Andrade, 1934b) e aquelas de $1944 .{ }^{28}$ A seqüência de revisões opera basicamente por acréscimos interpostos ao longo de um texto cujo eixo central está definido desde o começo. Esse procedimento (acréscimos de notas, de bibliografia, e sobretudo de trechos inéditos ou já redigidos para outros propósitos) torna a composição do texto final curiosamente semelhante ao próprio processo de composição das danças dramáticas tal como descrito por Mário de Andrade: inchado de elementos que recheiam o argumento central num intrigante processo de "justaposição discricionária".

\section{O texto}

Certamente, Mário de Andrade era um autodidata nos assuntos de folclore e antropologia. É preciso ter em mente sua relativa exterioridade do iniciante mundo acadêmico das ciências sociais que, entre as décadas de 1930 e 1940, desenhavase com frouxas fronteiras em São Paulo (Peixoto, 
2002). Entretanto, mesmo considerando a ambivalência de Mário de Andrade para com o seu afã estudioso, o texto das DD pertence inequivocamente a esse homem de estudo que, a seu modo doído, ele também foi.

Nesse texto, quem fala, de certo modo ávido em posicionar-se como tal, é o Mário pesquisador alçando vôo ambicioso. Alguns rompantes expressivos emergem aqui e ali. Ele não resiste a nos contar que foi sua "curiosidade apaixonada pelas coisas do povo" (Andrade, 1982, p. 43) que o conduziu, em 1927 no Alto Solimões, a uma Ciranda. Por sinal, presenciada apenas parcialmente, porque "sua paixão folclórica" já o fizera atrasar a partida do navio que aguardava no porto. Diversas formulações aparecem despretensiosamente como de suas "sensações" (Idem, p. 30, por exemplo). Entretanto, a abundância de citações bibliográficas, a utilização reflexiva de sua experiência de observação e registro das danças, o amplo desenvolvimento das notas e o desejo de sistematização de informações reunidas "por toda a documentação que conheço” (Idem, p. 46), estabelecem a linha dominante do texto, marcado também pela inquieta busca de sentidos primordiais.

O artista evidentemente lá está, fascinado pela dimensão expressiva das danças. Porém isso não lhe basta, e o estudioso é, também, fortemente atraído pela necessidade de lhes dar coerência conceitual, e de entender-lhes a origem. A expressão "danças dramáticas" foi cunhada, justamente, com o intuito de revelar a unidade subjacente a fatos culturais até então chamados por diferentes nomes. Muito da dificuldade do texto resulta do entrecruzamento desses diversos veios de indagação.

No ponto de partida do investimento reflexivo está o interesse fundamental de Mário de Andrade pela música. As danças dramáticas são, como nos diz a primeira frase do texto, "uma das manifestações mais características da música popular brasileira" e, mais do que isso, um ponto em que o povo teria evolucionado bem "sobre as raças que nos originaram e as outras formações nacionais da América" (Idem, p. 23). Mário de Andrade enxerga nessas danças uma solução brasileira e original ("bem evolucionada") de cultura popular: há aí dinamismo e criação. Ponto decisi- vo se lembrarmos de sua idéia acerca da precariedade brasileira de tradições próprias (Moraes, 1978; Travassos, 1997).

Porém há mais. A música o conduz, é certo. Entretanto, a associação entre música, dança e drama encontrada nessas formas populares parece sugerir solução a um dos problemas críticos da busca estética de Mário de Andrade, o da integração entre arte e vida. Na dança companheira da música, há expressão artística realizada numa forma plena de vida. ${ }^{29}$ Diante dessa percepção, se adotarmos um ângulo de leitura já bastante enfatizado por diversos estudiosos, essas danças seriam, digamos, arte com imediata "funcionalidade social"; e com isso insinuam-se os já bem conhecidos desdobramentos ideológicos que conferem à idéia mesma de folclore uma clara expressão nacionalista. Há, entretanto, um outro ângulo possível em que se destaca a percepção pura (isto é não instrumental ou ideológica) de uma outra estética. $^{30}$ Nesse folclore, o corpo humano, expressando-se por inteiro e coletivamente, é ele mesmo o veículo de formas artísticas. ${ }^{31} \mathrm{~A}$ integridade dessa forma de expressão comovia Mário de Andrade.

O último relato do segundo diário do "Turista aprendiz", feito na Paraíba (5/2/1929, às 23 horas), ${ }^{32}$ bem demonstra o tipo de emoção suscitado por esses bailados em nosso autor:

Não tem cantigas e só de longe em longe uma fala, tão esquematizada, tão pura que atinge o cúmulo da força emotiva. Imaginem só: fazia já mais de uma hora que o pessoal estava dançando, dançando sem parada, com fúria. Matroá é uma das figuras importantes do baile. É o "caboclo velho", de-certo, espécie de pajé da figuração tribal da dança. De-repente Matroá principiou uma coreografia de arquejo, brutal, braço esquerdo engruvinhado, com o arco por debaixo, duas mãos no peito, segurando a vida. Cada vez mais. Curvando, curvando, já levantava os pés custoso. O apito bateu duas feitas, parou tudo. O Reis falou pra Piramingu, "Caboclo menino":

- Piramingu!

- Sinhô.

- Mataram nosso Matroá.

Tururu, tarára, tururu, tarára...” a solfa continuou. O bailado se moveu de novo e Matroá foi enro- 
lando uma perna na outra, já não levanta pé do chão mais não, levou uns 10 minutos se movendo em pé, difícil de morrer como em todos os teatros e na vida.

Isso é que é perfeição! Fiquei tonto. Aquelas palavras puras, só aquilo. Fiquei com dó, não sei como fiquei, fiquei tonto, está certo, numa comoção danada.

Matroá levou um tombo e principiou se estorcendo. Então os bugres de mentira principiaram uma figuração nova, circulando em torno do moribundo e acabando com a vida dele, frechando-o. Matroá se defendia, também frechando pra um lado e pra outro. De-repente se levantou, vivinho. A dança da morte acabara e Matroá dançava como todos vivo feito eu e vós (Andrade, 1976, p. 320).

Mário de Andrade buscava no folclore formas expressivas capazes de provocar identificação e emoções genuínas. Buscava a beleza resultante disso. ${ }^{33}$ Não é outra, me parece, a razão de sua impaciência, e mesmo do desânimo com a monotonia ou a falta de jeito de certas apresentações de bailados que embasam, por vezes, o sentimento de "decadência" dessas formas. Nosso autor impacienta-se com a "falha" (Leiris, 2002), parte integrante da graça antropológica, e não exclusivamente estética ou expressiva, de rituais que dependem fortemente da destreza e do talento de seus agentes.

\section{O Conceito}

Junto com essa busca artística, está o empenho estudioso em conceituar, com a noção de danças dramáticas, a natureza de fatos culturais dispersos e entretanto aparentados. Nessa conceituação, o movimento do pensamento de Mário de Andrade assemelha-se, ele mesmo, a um bailado dramático ora comovido, ora hesitante, ora lúcido e tenso, e finalmente trágico. Dada a complexidade da argumentação, desdobrei a procura de unidade conceitual em três planos entremeados no texto: forma estética, conteúdo temático e origem comum.

a) Forma estética

A definição formal enfatizou a presença da dança companheira da música e da dramatização de um tema nesse tipo de fato cultural. O enfo- que a comandar o olhar é o do músico, pois esses bailados "obedecendo a um tema dado tradicional, respeitam o princípio formal da suíte, i.e. obra musical constituída pela seriação de várias peças coreográficas" (Andrade, 1982, p. 71, n. 1). A ele, soma-se contudo o gosto pelo dramático, em especial pela teatralidade dialogada. ${ }^{34} \mathrm{Em}$ particular, a forma rapsódica de composição, comum a todas as danças, revelar-se-ia especialmente nítida no Bumba-meu-boi. A idéia de suíte, que indica composições musicais de natureza também coreográfica, alarga-se na conceituação de Mário de Andrade, abrangendo a dimensão dramatizada do folguedo.

A tensão entre uma visão mais integrada e outra mais fragmentária das danças dramáticas, que se desdobrará ao longo de todo o texto, se faz imediatamente presente.

A visão mais integrada emerge sub-repticiamente em uma das definições mais utilizadas por outros pesquisadores:

[...] as danças dramáticas se dividem em duas partes bem distintas: o cortejo, caracterizado coreograficamente por peças que permitem a locomoção dos dançadores, em geral chamadas de "cantigas"; e a parte propriamente dramática, em geral chamada de "embaixada" caracterizada pela representação mais ou menos coreográfica dum entrecho, e exigindo arena fixa, sala, tablado, pátio, frente de casa ou igreja (Idem, p. 57, grifo meu). ${ }^{35}$

Um trecho da primeira versão da redação das DD, depois retirado, permite perceber claramente a valorização da unidade intelectual e estética propiciada pela idéia de um "entrecho dramático":

Tive ocasião de assistir a um Boi Bumbá - nome amazônico do BMB, na cidadinha de Humaitá no Madeira. Colhi mesmo dela várias cantigas. Era uma peça admirávelmente unida, em que todos os episódios se juntavam ao núcleo de morte e ressurreição do boi, sempre em referencia com ele. Era legitimamente o Reisado do Bumba-meuboi a que apenas tinham se ajuntado episódios desenvolvidos do próprio assunto. É o que se á também ainda com as cheganças, com os congos, em que por enquanto os episódios esporádicos ainda são ajuntados de maneira a constituir um todo harmonioso, mais ou menos, como foi a for- 
mação da Odisséia, quer ela tenha como autor Homero ou o tempo (1934a, p. 19).

Entretanto, ao mesmo tempo, a visão mais fragmentária também se apresenta. Pois, a dança dramática do bumba-meu-boi não seria, nos diz o autor logo a seguir na versão publicada das DD:

[...] um todo unitário em que se desenvolve uma idéia, um tema só. O tamanho dela, bem como seu significado ideológico, independe do assunto básico. No geral, o assunto dá ensejo a um episódio só, rápido, dramaticamente conciso. E esse núcleo básico é então recheado de temas apostos a ele; romances e outras quaisquer peças tradicionais mesmo de uso anual se grudam nele; textos e mesmo outros núcleos de outras danças se ajuntam a ele. Às vezes mesmo estas aposições não têm ligação nenhuma com o núcleo (Andrade, 1982, pp. 53-54, grifo meu)

A unidade formal das danças dramáticas oscila então entre uma definição integradora, que postula a existência de um núcleo temático básico a comandar as agregações por aposição, e uma visão fragmentária, em que os temas agregados não teriam mesmo nenhuma ligação com o suposto núcleo. Apesar da aparente contemporaneidade dessas duas maneiras de existência dessas danças, a visão fragmentária associa-se à presença das deletérias influências urbanas e aos males da civilização. Mário de Andrade hesita contudo todo tempo entre essas duas visões, e a brecha aberta para a fragmentação desordenada, por sua vez associada à perda do caráter sintético e dramático do "núcleo básico", terá importantes conseqüências na solução do texto.

b) Conteúdo temático

A unidade do motivo simbólico remete ao assunto do fato cultural em questão, a princípio acolhido e exposto na representação do "entrecho" ou do "núcleo básico" acima mencionados. Porém, acabamos de ver como o autor nos disse também que o tamanho e o significado ideológico do bailado do Bumba-meu-boi "independem do assunto básico". O desenvolvimento do argumento opera com essa imprecisão.
As danças dramáticas abarcariam Pastoris, Cheganças e Reisados. ${ }^{36} \mathrm{Na}$ distinção estabelecida entre este último e os dois primeiros, há uma nítida hierarquia de ancestralidade cultural. De imediato, o tema da "morte e ressurreição da entidade principal do bailado" destaca-se, ocorrendo "no Bumba-meu-boi, nos Cabocolinhos, nos Cordões de Bichos amazônicos, ainda nos Congos, nos Cucumbis e nos Reisados [...]" (Idem, p. 25). Reisados, então, é o termo escolhido para englobar toda essa classe de danças que tematizam "sempre o assunto de imemorial significação mágica em que se dá morte e ressurreição do bicho ou planta” (Idem, p. 39). Já nos Pastoris e Cheganças,

[...] danças dramáticas de origem proximamente ibérica [...], há somente o elemento fundamental de qualquer drama [...] isto é a luta de um bem contra um mal, que os bailados coletivos, e por isto infensos aos sentimentos individualistas (principalmente amoroso), caracterizam na noção de perigo e salvação (Idem, p. 25).

Nesse caso, o tema aglutinador seria o princípio da oposição entre o Bem e o Mal (Idem, p. 39). ${ }^{37}$

$\mathrm{Na}$ fundamentação do conteúdo simbólico, parece predominar a visão mais integrada da unidade formal apresentada no item anterior. O "tema" é exposto no "núcleo básico", e funciona como "princípio de agregação" a presidir e ordenar a seriação e a justaposição características das diversas peças musicais e dramáticas que compõem esses bailados.

\section{c) Origem comum}

Um terceiro plano de reflexão busca uma origem comum às danças dramáticas, e a identificação das influências recebidas por elas ao longo do tempo. É um terreno movediço, sobretudo se atentamos para o fato de que a idéia de história deslocase por vezes para uma mito-história e expressa-se freqüentemente num difusionismo desenfreado. ${ }^{38}$

Em Mário de Andrade, essa busca de origens norteia-se implicitamente pela definição formal das danças dramáticas que, como vimos, privilegia música, bailado e dramatização de um tema. A documentação conhecida indicaria uma ex- 
traordinária floração dessas danças em fins do século XVIII e início do XIX, concomitante à formação de uma cultura popular de ampla base católica. ${ }^{39}$ Essas danças encontraram abrigo nas datas festivas desse calendário, em especial o natal, o carnaval e os santos de junho. ${ }^{40}$ A primeira parte é um cortejo, e cortejos foram sistematicamente usados pelos jesuítas no Brasil no processo de cristianização que convertia cerimônias pagãs em procissões católicas.

Essas folias com que não apenas os "negros" destas Índias Ocidentais, porém ainda os "negros da Guiné", e mesmo os brancos acompanhavam com danças as procissões católicas, foram certamente no país o maior incentivo para a tradicionalização do princípio do cortejo-baile, usado pelas nossas danças dramáticas (Andrade, 1982, p. 33).

O caráter dramático das danças, por sua vez, encontraria raízes nas Paixões da Idade Média. ${ }^{41}$ No Brasil, o povo teria recorrido aos temas dos romances ibéricos para teatralização. A origem dos diversos Reisados residiria nesse notável processo de transposição de uma forma verbal e poética à forma dramática dançada. ${ }^{42}$ Porém, nesse conjunto, o Bumba-meu-boi ocupa lugar ímpar e de certo modo anômalo.

\section{Os Reisados e o Bumba-meu-boi}

Mário de Andrade enumera os 24 reisados "que os livros me indicam" (Andrade, 1982, pp. 5053). Nessa enumeração, as distinções estabelecidas insistem em se confundir, sugerindo ao leitor contemporâneo, sobretudo, a presença de um universo cultural de extrema mobilidade formal. Assim, por exemplo, o reisado da "Barca Bela" está na "Chegança de Marujos cearense", tendo se enquistado entre nós no romance da Nau Catarineta (Idem, pp. 50-51); e nove reisados relacionados já se encontrariam, nos idos de 1930, agregados ao Bumba-meu-boi: "o mais importante de todos, que fazia parte final obrigatória de todos os Reisados. Espalhado por quase todo o Brasil, permanecido muito vivo até agora", especialmente nas regiões do Norte e Nordeste do país (Idem, p. 50).
No entanto, vale observar que, à diferença dos demais reisados, para os quais se identifica $O$ romance que estaria na origem da dramatização dançada do tema, ${ }^{43}$ não há para o Bumba-meu-boi nenhum romance. No Bumba, o tema do "entrecho", elemento que fornece um princípio de unidade ao bailado seriado, é essencialmente "mítico", vem de camadas de humanidade mais profundas. ${ }^{44}$ Essa é, parece-me, uma das razões importantes da primazia desse reisado sobre os demais. O Bumba emerge como elo da cultura popular brasileira com uma dimensão humana universal. Talvez possamos derivar daí, também, o seu poder de atração como grande "aglutinador" de outros reisados.

O Bumba-meu-boi é tema "mítico" por excelência, expressão do primitivo e do ancestral. Nessa condição, o folguedo expressa a unidade básica do humano tão cara ao evolucionismo. Em Mário de Andrade, essa unidade transforma-se também em expressão possível de uma universalidade (mais do que propriamente uma unidade) brasileira. O autor idealiza e transfigura o Boi. A cadeia de raciocínios é tortuosa, cheia de lapsos preenchidos por malabarismos mentais.

Mário de Andrade é agora um evolucionista intelectualista, envolto nos meandros do ramo dourado de Frazer e seduzido pela possibilidade de raciocinar tal qual um primitivo sugerida pela leitura de Tylor. Desvenda então o "mistério" que, na mentalidade primitiva, "idêntica nesse ponto à popular, pode explicar outro mistério ou qualquer realidade".

Desprovido das defesas da técnica, na sua luta contra... o resto, incapaz ainda de a organizar de maneira eficaz, se afirma no primitivo a noção de uma força superior à dele, e que ele aplica imediatamente aos animais, vegetais, minerais e fatos [...]. E assim, se nas culturas primitivas surgiu na forma de magia homeopática, mimética, o culto do vegetal, da primavera, Perséfona, o totem, e principalmente, por mais genérica, a noção de morte e ressurreição da terra, do sol, do boi, do bicho, do vegetal, de deus [...] (Idem, p. 24).

Se o tema da morte e da ressurreição é motivo humano primevo, imposto pelo renovar dos ci- 
clos naturais da vegetação, a predileção pelo Boi no Brasil teria também razões especificamente brasileiras. O centro econômico da colonização teria sido o Boi, verdadeiro continuador dos desbravamentos interioranos iniciados pelos bandeirantes nos séculos XVI e XVII (Lopez, 1972, pp. 127 ss.). Nada mais "natural" do que sua valorização mítica.

A própria variação da inserção do Boi no calendário católico popular que intriga o autor pois o Boi é encontrado no Norte entre as festas juninas e, no Nordeste, nas festas natalinas - encontraria resposta plausível pelo viés de sua leitura frazeriana. Lopez transcreve uma ficha manuscrita, que bem demonstra a natureza do anseio intelectual de Mário de Andrade:

Bumba meu Boi ou Boi Bumbá! O Boi mal comparando, parece assumir uma posição de Dionísio, símbolo do reflorescimento e do tempo fecundo. Ora é curioso pois que a celebração dele no Norte venha justamente em junho, tempo de inverno, tempo de cheia nos rios, tempo de menos febre, mais facilidade na vegetação ao passo que no Nordeste está também quando chega o que por lá chamam de "inverno", tempo de Natal, tempo das águas, tempo de reflorescimento, e de muito mais facilidade. Parece haver uma razão profundamente humana e a seu modo religiosa nessa escolha de datas (apud Lopez, 1972, p. 128).

Em ambos os casos, estaríamos diante do apogeu da vegetação cultuada por meio do sacrifício de seu símbolo animal, o Boi. ${ }^{45}$

Porém, esse sentido mais profundo e pleno já se teria perdido. Para usarmos uma noção importante em Tylor, o Boi seria "sobrevivência", ${ }^{46}$ noção que Mário de Andrade parece ter fundido com suas leituras freudianas na noção de "sintoma". O Boi, como nos diz Telê Ancona Lopez, é "sintoma-Brasil" (1972, p. 132). Um fato cultural revelador de uma possível universalidade brasileira:

Mas, no Brasil isso é assombroso. E o Bumba representa porventura a mais bela noção crítica de nosso fenômeno nacional, tirada inconscientemente pelo povo brasileiro. Unidade de língua, unidade de religião, várias são as razões inventadas para designar esse fenômeno absurdo que é a unidade brasileira. Talvez fosse mais razoável indicar a unidade do boi. O boi é realmente o principal elemento unificador do Brasil (apud Lopez, 1972, pp. 131-132).

\section{Tensão: fragmentação e integração}

Entre todas as danças dramáticas, destacarse-iam, portanto, os Reisados, e dentro deles o Bumba-meu-boi por sua ancestralidade, universalidade e brasilidade. Nessa valorização, desenhase uma forte tensão. Pois, de um lado, os Reisados emergem tal como concretamente encontrados por Mário de Andrade: aglutinados e justapostos, num processo em que o Bumba seria, por assim dizer, um reisado expansionista a impor aos outros uma espécie de hegemonia dramática. Contudo, de outro lado, está a idéia de uma "integridade" originária, expressa na representação de um "entrecho", exigência ideológica de síntese: "Sobretudo é isso que é o Reisado: uma representação dançada e cantada, consistindo num episódio só que contém sinteticamente a significação completa do assunto" (Andrade, 1982, p. 53).

Mário de Andrade viu-se então, talvez à sua própria revelia, levado a dar conta da distância que separava o estado dos Reisados, tal como testemunhado por ele, e a suposta integridade original, cujos efeitos expressivos ele parece ter também experimentado, ao menos emocionalmente, em certas ocasiões felizes, como no episódio "Matroá" citado acima. ${ }^{47}$ De forma consciente, levemente irônica, Mário de Andrade inventou uma história totalmente especulativa da evolução formal das danças dramáticas: "Parece porém que desde logo ou desde sempre [grifo meu], a curteza esteticamente admirável do reisado se tornou insatisfatória ao povo". [Andrade, 1982, p 53]. A "psicologia popular" adepta das "criações artísticas alongadas", logo teria começado a reunir dois ou mais reisados. Nesse processo, o "complexo do boi" tornou-se dominante:

Ficou assim um reisado único, que não tem popularmente este nome, a dança dramática do Bumba-meu-boi, que embora não seja nativamente brasileira, mas ibérica e européia, coinci- 
dindo com festas mágicas afro-negras, se tornou a mais complexa, estranha, original de todas as nossas danças dramáticas. Por vezes, mesmo uma verdadeira revista de números vários, com a dramatização da morte e ressurreição do boi como episódio final (Idem, pp. 53-54).

Além da hesitação intelectual entre as origens "histórico-raciais" do bailado, o ponto é crítico. Revela um desencontro profundo entre aquilo que a sensibilidade artística de Mário de Andrade buscava, e por vezes de fato encontrava a curteza expressiva admirável que o comovia -, e aquilo que o pesquisador encontrou com mais freqüência diante de si - a desorganização da indefinição de formas, um mundo festivo em estado de permanente mutação, que contrariava o desejo de "fixar" uma forma expressiva como ideal. Nas entrelinhas do texto, esse desencontro produz um grau de tensão que beira o dilaceramento. A integridade inicial suposta e procurada (talvez nos aproximemos aqui da idéia da "falta de caráter" de seu anti-herói nacional) colide com a avaliação predominante da realidade encontrada e se traduz em forte ambivalência na valoração do Bumba-meu-boi.

Talvez por isso, o Bumba seja a um só tempo estranho e original, exemplar e complexo. Como se o bailado explicitasse também uma exigência existencial insatisfeita. Desse modo, ao longo do texto, o mesmo processo de composição rapsódica que tanto fascinou Mário de Andrade vai ganhando também sinal negativo nas considerações tecidas acerca do estado atual [1934/1944] e futuro do Boi. O "núcleo íntegro" do Bumba-meu-Boi, "contendo como drama único a morte e ressurreição do grande bicho servil, cercado dos seus personagens humanos tradicionais" persistiria apenas "em certos Bois-Bumbás do Amazonas” (Idem, p. 54). A característica justaposição de temas, vista em outros momentos como original e mesmo exemplar, surge também como sintoma de perda e deterioração da integridade primeva, que Mário de Andrade sabe entretanto, confusamente, nunca ter existido.

Nem por isso a idéia deixa de ser bastante ativa. No processo mesmo de conformação por agregação e justaposição de temas, o assunto nu- clear tornar-se-ia tradição esquemática e as partes fixas perderiam gradativamente sentido. Em sua briga com a civilização, as danças dramáticas estariam "em plena, muito rápida decadência. Os reisados de muitas partes já desapareceram". Apenas no Norte e no Nordeste, eles persistiriam sua furiosa luta. É um Mário de Andrade triste e trágico quem vaticina "Da maneira como as coisas vão indo, a sentença é de morte" (Idem, p. 70).

\section{Alguma conclusão}

A combinação entre exemplaridade e estranheza sinaliza a extrema ambivalência de Mário de Andrade para com o Bumba-meu-boi. Aquilo mesmo que tanto o fascinava parece ter correspondido apenas raramente a suas expectativas de integridade e síntese estéticas. Laço desfeito ao ser encontrado. O "desde logo ou desde sempre", tão significativo no trecho citado sobre a evolução dos reisados, não deixa de expressar formas de pensar que, ainda que ironizadas, têm conseqüências importantes na solução do texto e um imenso impacto na visão subseqüente de diversos pesquisadores acerca da brincadeira.

Com relação a esse último aspecto, lembro a conclusão de Mello e Souza que, retomando a indicação pessimista do próprio Mário de Andrade, viu Macunaima como obra "ambivalente e indeterminada, sendo antes o campo aberto e nevoento de um debate do que o marco definitivo de uma certeza" (1979, p. 97). Creio que, inadvertidamente, as formulações de Mário de Andrade nas DD forjaram uma maneira de ver a brincadeira do Boi que, contendo percepções luminosas, lançou também sobre ela uma vasta neblina. Além da temática mais evidente da deterioração, especialmente influente, e particularmente nebulosa, é a idéia de um núcleo de sentido compreendido de forma fixa a presidir a unidade da brincadeira. ${ }^{48}$ Essa idéia, associada a uma perspectiva racialista de cultura, parece estar na base de visões reificantes e extremamente difundidas dos processos de simbolização presentes na cultura popular.

Com relação à argumentação do próprio texto, o desenlace de tamanha ambivalência é um 
decreto de morte de tonalidade trágica. O boi como "sintoma-Brasil", como brasilidade buscada, estaria, ele também, fadado ao fracasso. O Bumba-meu-boi surge efetivamente como um operador de passagens no pensamento de Mário de Andrade. Mello e Souza (1979, p. 16) ressaltou a sugestão do autor da existência de afinidades estruturais entre Macunaima e o bailado popular que, a seu ver, melhor representava a nacionalidade. Assinalou, nessa direção, como prenúncio do desenlace trágico do romance, a utilização de um longo trecho do bailado que termina com a morte do boi no capítulo "Uraricoera" que precede a morte do anti-herói, com sua transfiguração em estrela de brilho inútil. Nesse episódio, a sombra que persegue Macunaíma, confunde-o com um boi malabar "chamado Espácio que viera do Piauí” (Andrade, 1978, pp. 200-203). E mata-O como que por encosto, ela é quem engole a sua comida. O Boi esverdeia de fome, morre e apodrece. Urubus o rodeiam e, cantando e dançando, dividem entre si suas partes podres. Dessa refeição ritual degradada emerge a "festa famanada do bumba-meu-boi, também conhecida por BoiBumbá”. Mário de Andrade projetou sobre o boi não apenas suas aspirações nacionalizantes (o boi sintoma-Brasil) e criativas (o boi rapsódia-modelo de Macunaíma), mas também a busca de integração de sua própria subjetividade.

Em sugestivo artigo, Nicole Belmont (1986) assinalou a ambivalência da relação da etnologia francesa contemporânea com o folclore. Numa avaliação que pode ser transposta para a contemporaneidade da antropologia no Brasil, a autora nota a dificuldade existente mesmo quando se trata de reconhecer o folclore como etapa histórica do estudo das sociedades e culturas da Europa. Os estudos de folclore teriam perdido crédito à medida que a etnologia clássica penetrava na França, e esse processo se teria tornado irreversível por volta de 1950. No entanto, como os "fatos folclóricos" crenças, práticas e rituais populares - são dotados de grande capacidade de persistência e de grande poder de sedução, esses materiais reintegram-se sub-repticiamente em análises contemporâneas. O folclore estaria assim condenado a uma espécie de "retorno do reprimido". ${ }^{49}$ Pois, ao reinserir esses fatos na análise contemporânea, seríamos seduzidos pela ilusão do arcaísmo, pela idéia do bom tempo de outrora quando as produções populares não apresentavam descontinuidades, eram coerentes e facilmente acessíveis à interpretação. Os materiais folclóricos, nos sugere a autora, chegam até nós, estudiosos contemporâneos, carregados de arcaísmos. Belmont propõe então o exame do arcaísmo inerente a esses materiais como sintomas, na acepção psicanalítica do termo.

Saltando sobre o abismo que separa representações da psicologia individual da psicologia coletiva, a autora chama atenção para a observação de Freud de que os sintomas neuróticos de eventos traumáticos não emergem de um passado distante, mas se formam no momento da evocação. No universo da própria cultura popular, o arcaísmo assumiria feições de mito, na acepção estruturalista desse conceito..$^{50}$ Contudo, quando tornado moeda corrente nas visões sobre a cultura popular nos circuitos intelectuais e eruditos, o arcaísmo assumiria a forma de ilusão. Essa ilusão é a base do efeito neblina que identifico nas formulações andradianas sobre o Bumba-meu-boi, as quais tornaram o folguedo o envolvente símbolo de ancestralidade, universalidade e originalidade.

Porém, no plano do próprio pensamento de Mário de Andrade, o Boi assume também um caráter sintomático, opera conexões de sentido entre a expressão de sua subjetividade, a busca ideológica e estética da brasilidade e o esforço de conhecimento existencial e intelectual da cultura popular. O Boi traz à cena de seu pensamento, a um só tempo, a diferença, a ancestralidade e uma insinuante desordem que desfaz continuamente esforços de ordenação e de satisfação. Atiça e exaure a curiosidade intelectual, provocando simultaneamente, como as lembranças de infância, os sintomas neuróticos e os sonhos mencionados por Belmont "estranheza, incompreensão, desconforto e sedução" (1986, p. 266). Exemplar: o mais estranho e original entre todas as danças.

\section{Notas}

1 Gomes (1998) lembra-nos que o sentimento de compartilhamento da intimidade é ilusório: o que 
acessamos num texto, mesmo de natureza confessional, é sempre a elaboração de uma representação de si por parte do autor.

2 Como já disse, com felicidade, Carlos Sandroni (1992, p. 83), "quando nos reunimos em torno desses assuntos [folclore e cultura popular] estamos de alguma forma sentados à mesa desse banquete em que ele [Mário de Andrade] se perpetuou - e sem dúvida, já sentimos em nossas bocas, com maior ou menor intensidade, um sabor de Mário de Andrade”.

3 Por sinal, em 1/6/1927, Mário de Andrade esteve em Parintins, onde os dois Bois que hoje brincam já existiam desde 1912/1913, mas ele nem os viu e nem os menciona. Chegou de tarde numa breve pausa de viagem. Em 29 de maio, estava em "pleno Amazonas", na foz do Tapajós, tendo parado em Itamarati no dia seguinte. Depois disso, a comitiva desceu em Parintins, onde encontrou um "prefeito bem falante". Nosso autor oferece a seus leitores o "Apostolado da oração", cujas regras encontradas na visita à igreja local, muito significativamente estabeleciam que seus fiéis: " 1 - Renunciam totalmente às danças; 2 - renunciam a máscaras e fantasias; 3 - não tomam parte em festas particulares, etc. [...]". O grupo seguiu para Itacoatiara a caminho de Manaus. Na volta, em 23 de julho, o diário registra "Parintins pela madrugada, vista em sonhos" (Andrade, 1976, p. 76).

4 Acompanho, por esse viés, a proposta de Geiger de aproximação e reconhecimento de afinidades entre a antropologia como disciplina e o momento "romântico" do modernismo brasileiro. Segundo o autor, o não reconhecimento disso implicaria em "deixar de exercitar [...] o que houve de impulso cognitivo qualitativo nos anos 20" (1999, p. 121). Por sinal, a idéia de que a antropologia se empobrece ao forçar a alteridade com certas áreas "ancestrais" está na base de pesquisa sobre os estudos de folclore no Brasil. Ver Cavalcanti et al. (1992), Cavalcanti e Vilhena (1990) e, em especial, Vilhena (1997). Esse ponto será retomado na conclusão deste trabalho.

5 Meu argumento, de colorido "anti-romântico", situa o festival de Parintins - com toda alta tecnologia, turismo, mídia e comercialização - como uma variante ritual que integra e atualiza um padrão recorrente da brincadeira do boi, registrada no país desde a primeira metade do século XIX. Fragmentação e maleabilidade são entendidas como características positivas constituintes do folguedo. Sob esse aspecto, a interpretação proposta afasta-se criticamente da idéia da deterioração e inexorável perda das tradições populares tão recorrente em tantos estudiosos dos fatos populares, entre eles Mário de Andrade. Sobre o festival de Parintins, ver ainda Cavalcanti (2002).

6 As formulações de Claude Lévi-Strauss são referências centrais para o entendimento contemporâneo da noção de mito (1964, 1970, 1971). Para a noção de mito com que Mário de Andrade trabalhava, as referências principais são as obras de Frazer, Tylor e Lévy-Bruhl.

7 Ver também Cavalcanti et al. (1992 ) e Peixoto (2002).

8 Margarida Souza Neves e Ilmar Mattos coordenam na PUC/RJ o projeto de pesquisa intitulado "Modernos Descobridores do Brasil". Sobre Mário de Andrade, ver Neves (1998).

9 "Improviso do mal da América" (fevereiro de 1929), Andrade (1993, p. 265).

10 Ver, por exemplo, Fernandes (1989). Sergio Miceli (1998), numa resenha sobre o livro de Luis Rodolfo Vilhena (1997), chamou os estudos de folclore de "disciplina de amor".

11 Tanto Travassos (1997, pp. 202-203), como Moraes (1999, p. 31) encontraram essa dimensão filosófica profunda do romantismo no modernismo de Mário de Andrade.

12 O sentimento é expresso por vários folcloristas. Ver, por exemplo, o forte "pessimismo com relação aos tempos atuais" que, conforme indicado por Abreu (2001), perpassa a relação de Cecília Meireles com o folclore. A atuação do Movimento Folclórico Brasileiro e da Campanha Brasileira de Defesa do Folclore (Cavalcanti et al., 1992, e Vilhena, 1997) tiveram em sua raiz a idéia da "proteção do folclore", numa tentativa de evitar o desaparecimento iminente das práticas tradicionais do povo. Essa visão embasou a atuação pública nacional até a década de 1980.

13 Edmund Leach (1980) lembra-nos do mito da Idade de Ouro e da expulsão do Paraíso como formas míticas explicativas dos horrores da civilização. Lovejoy (1965), examinando o primitivismo na Antigüidade, distingue duas acepções da noção. A primeira seria o primitivismo cronológico, que alinhando passado, presente e futuro atribui ao passado a melhor condição da vida humana. A segunda, o primitivismo cultural, expressaria de outro modo o "malestar" civilizatório, acreditando que a vida tida como mais simples e menos sofisticada de outros grupos humanos seria sob todos os aspectos uma vida mais desejável. 
14 Trata-se do poema "Eu sou trezentos..." (7/6/1929), do livro Remate dos Males [1930] (Andrade, 1993, p. 211). De modo arguto, Rosenfeld assinala o recobrimento em Mário de Andrade da busca da identidade nacional (no plano do próprio idioma) pela busca de sua própria identidade pessoal. No roldão, o sugestivo tema da "sinceridade" e do "cabotinismo", que discute e retoma o exame do próprio Mário de Andrade acerca desses temas [1939] (2002a).

15 O título do trabalho pioneiro de Lopez é muito sugestivo - Mário de Andrade: ramais e caminhos. A extraordinária tarefa de organização de suas obras completas, incluindo importantes edições póstumas em que se destacam os trabalhos de Alvarenga e Lopez, as edições das correspondências ainda por vir, a existência do IEB/USP, propiciando excelentes condições de consulta a seus arquivos, não só atendem como ampliam imensamente esses apelos.

16 Mello e Souza argumenta que o processo de criação do romance tranpôs "duas formas básicas da música ocidental, comuns tanto à música erudita como à criação popular: a que se baseia no princípio rapsódico da suite - cujo exemplo popular mais perfeito podia ser encontrado no bailado nordestino do Bumbameu-boi - e a que se baseia no princípio da variação, presente no improviso do cantador nordestino, onde assume forma muito peculiar" (1979, p. 12).

17 Esse mesmo ponto, por sinal, é a base do argumento de Moraes (1999).

18 Interessante observar a coincidência com a visão adotada por Joaquim Pedro de Andrade em seu filme, que acentua Macunaíma como um herói vital, mas inconsciente. O "moderno" apareceria na busca dessa elaboração consciente, empreendida pelo romance, ou pelo filme ( cf. Buarque de Hollanda, 1978, pp. 125-126).

19 Versos do poema "Danças" [1924] (Andrade, 1993, pp. 215-223)

20 Ver Lopez (1972, pp. 77-90).

21 Carão é um tipo de pássaro encontrado nas Américas Central e do Sul, e em todo território brasileiro.

22 A crônica foi publicada no apêndice do Turista Aprendiz, pp. 335-336. A editora/pesquisadora observa que dessa primeira viagem alguns outros trechos ainda figuraram como crônicas.

23 Mário de Andrade destaca a beleza do lamento coral da morte do carão, revelador de uma coindicência com cantos populares escandinavos que o deixa "atarantado": "Porque os elementos melódicos originais são verdadeiras sínteses étnicas e parece inconcebível que a tapuiada caiçarense tenha concebido certos movimentos sonoros que são normas nacionais dos nórdicos europeus" (1976, p. 336).

24 Ver, a esse respeito, Andrade (2000), Byington (2000) e Gico (2002).

25 Cecília Mendonça (2002) examinou, nos três tomos das $\mathrm{DD}$, os escritos que acompanham a coleta empreendida, organizada em torno de cinco principais danças: o Pastoril, a Chegança, o Bumba-meu-Boi, o Maracatu e os Cabocolinhos. Como informa Lopez, além das "danças dramáticas", outros interesses derivarão da viagem: as melodias do boi, a música de feitiçaria, a religiosidade e a poesia populares (1972, p. 21).

26 Lopez transcreve, com zelo, anotações de leitura de Mário de Andrade que indicam suas interessantes discordâncias com Lévy-Bhruhl (1972, p. 99). Ressalta também o impacto da idéia frazeriana de culto vegetal primordial através do "bumba" anotado nas margens do texto de Frazer (Idem, p. 127).

27 Esse material encontra-se hoje, graças ao trabalho do IEB, mais completo e acessível do que à época da edição dos tomos por Alvarenga. Assim é que, em janeiro de 2003, além das quatro versões enumeradas por Alvarenga, encontrei no IEB a primeira versão do texto cuja existência, indagada pela pesquisadora, era tida como inexistente (Andrade, 1982, último parágrafo da p. 18 e o primeiro da $\mathrm{p}$. 19). Na primeira das três caixas de papelão que abrigam essa documentação, além do mencionado texto de seis páginas, "Origens das DD bras. Excerpto", há um texto de 27 páginas datilografadas em folhas azuis, cuja capa - uma folha azul com o título "Danças dramáticas, introdução e primeira versão" manuscrito a lápis - se encontrava deslocada de lugar (então MA - MMA 38, 157/158) no verso de uma página escrita, provavelmente re-aproveitada pelo autor. Indiquei então o fato à profa. Telê Ancona Porto Lopez. Vale observar também que, como assinalou Alvarenga em sua "Explicação" ao segundo tomo da série, essas versões são bastante ordenadas, "têm a mesma ordem expositiva, vão cronologicamente num crescendo de dados, têm indicação clara da substituição progressiva de umas às outras e são rematadas por uma versão impressa em 1944, absolutamente igual à última datilografada" (DDB, II Tomo, p. 12). O encontro dessa primeira versão só vem confirmar essas observações. Na bibliografia, indico essa primeira versão de 27 páginas como 1934a, e sua revisão de 36 páginas como 1934b. 
28 No trecho final da versão publicada, antes da sentença fatídica, há o seguinte trecho: "A decadência das danças dramáticas é estimulada pelos chefes, o seu empobrecimento é 'protegido' pelos ricos. E elas vasquejam agora, como o teatro ibérico ao nascer: Sin más hato que un pellico/un laúd y una vihuela/una barba de zamarro/sin más oro ni más seda" (Andrade, 1982, p. 70). Na primeira redação desse trecho final (Andrade, 1934b, p. 36), no lugar do segmento citado acima, antes da mesma sentença final, lê-se o seguinte: "Mas estas minhas melancolias não querem ter sinal de lei. Além da estupidez de muitos, fôrça é confessar que a própria civilização imprime ao povo uma andadura que não lhe deixa tempo mais prás grandes paciências que uma dança dramática exige. Isso também é certo: a tempo novo, psicologia nova. Mas não é menos certo que a psicologia tem bases inamovíveis (?) e na realização destas é que está a felicidade. Uma orientação esclarecida havia de permitir que as dansas dramáticas não morressem!". Visivelmente em 1934, Mário de Andrade tem mais fair-play e esperança.

29 Lopez (1972, p. 54) acentua a influência de Keyserling no pensamento do autor. Wisnik (1979, p. 64) assinala também a associação dança/drama/música.

30 Em seu último livro, Moraes (1999) propõe-se a demonstrar o arcabouço conceitual do pensamento estético de Mário de Andrade, tomando como ponto de partida a conferência "O artista e o artesão", proferida no final da década de 1930, na Universidade do Distrito Federal. Moraes ilumina a reflexão de Mário de Andrade acerca da relação existente entre o artista/indivíduo e a criação de sua arte, enfatizando o internalismo da visão andradiana que busca a dimensão social da arte no interior do fazer artístico individual. A discussão é sobre arte erudita, a "coisa folclórica" entra, nesse sentido, a serviço de um circuito erudito de criação artística. Dito de outra forma, a reflexão de Moraes incide, muito lucidamente, sobre questões levantadas no pensamento andradiano pela transposição das formas populares para uma nova e almejada forma de arte erudita. Mas o "folclore" existe, digamos, "lá fora" e por si só, e Mário de Andrade não quis só utilizá-lo como fonte de soluções para novas formas de arte propostas e experimentadas por ele. Parece ter também percebido nele uma diferença de certo modo irredutível, e não necessariamente "nacionalizável".

31 Além da noção de "participação", o gosto de Mário de Andrade pela "mentalidade pré-lógica" de LévyBruhl provém justamente da percepção de uma forma da inteligência "não fixadamente conceitual e abstraideira que nem a do intelectual culto" em que se pensa com todo o ser (Mário de Andrade, apud Lopez, 1972, p. 99). Por essa via, a indicação da importância da dança na reflexão andradiana merece aprofundamento. Também no "samba rural" e na "música de feitiçaria", as mesmas qualidades sinestésicas dessa música-que-é-dança parecem ter atraído o interesse estético e intelectual do autor.

32 Como informa Lopez (em Andrade, 1976), o texto foi publicado no Diário Nacional de 29 de março de 1929. Essa dança, por sua vez, "um cabocolinho", teve sua "documentação" publicada no segundo tomo das Danças dramáticas do Brasil. É um "cabocolinho" de João Pessoa, com a "Dança de Morte do Matroá" (Andrade, 1982, II tomo, pp. 198-199).

33 Ver, a esse respeito, Moraes (1999, p. 27). Em Mário de Andrade "a arte tem essencialmente uma função expressiva e os elementos estéticos - a beleza precisam ajustar-se a essa função". Ver, também, Travassos (1997), em especial o item "Virtudes do povo" (pp. 184 ss.). Sobre a forma como elemento estético imprescindível da atuação da obra-de-arte sobre o espectador, ver Andrade (2002).

34 "Em vez da descrição, que é um mecanismo intelectual mais complicado e completo, abrangendo o assunto por mil lados, o povo prefere criar na forma de diálogo, de que ele tem a amostra fácil no mecanismo cotidiano das suas comunicações. O diálogo evita a análise psicológica, evita a descricão de gestos e de ambientes, facilita a síntese dos recontos [...]" (Andrade, 1982, p. 47). Um dos indícios de decadência é, assim, a perda do caráter dramático do episódio principal.

35 Meyer (1991), Pereira de Queiroz (1967), Borba Filho (1966) estão entre os muitos autores que utilizam essa definição como ponto de partida de seus trabalhos.

36 Há uma quarta categoria enumerada por ele, os Ranchos e Ternos. Retiro-a pois logo Mário de Andrade afirma que reisado é a "obra de arte", ao passo que ranchos e ternos seriam apenas designações dos grupos de indivíduos que representam "um reisado ou qualquer outra das danças dramáticas” (1982, p. 46). Para as três primeiras categorias, ele baseia-se na distinção de Sílvio Romero (Idem, pp. 35-36), para quem os Reisados agrupariam "folganças muito variadas", apresentando sempre ao final de várias cantigas e danças, o brinquedo do Bumba-meu-boi.

37 Para Mário de Andrade, o princípio de oposição entre o bem e mal seria facilmente assimilável ao da 
morte e ressurreição. Quanto a este último, o leque simbólico é amplo, remetendo tanto a crenças pagãs antiquíssimas como ao mistério central do cristianismo. Mário de Andrade acredita tratar-se de "uma noção mística primitiva, encontrável nos ritos do culto vegetal e animal das estações do ano, e que culmina sublimemente espiritualizado na morte e ressurreição do Deus dos cristãos" (1982, p. 25). Muitos pesquisadores o seguem, entre eles Borba Filho, que se atém ao contexto cristão: "indiscutivelmente, o Bumba-meu-boi, em seus princípios, era um auto hierático, um reisado conclusivo sobre o boi da mangedoura do Nascimento de Nosso Senhor Jesus Cristo. Pouco a pouco outros reisados se foram juntando a ele, as marcas de cada época anexando-se ao espetáculo. O boi, como animal quase sagrado, também se foi fundindo com o boi da região pastoril, o profano invadindo o folguedo. Fenômeno idêntico ao do teatro litúrgico medieval [...]" (1996, pp. 19-20).

38 Esse recurso intelectual é muito freqüente entre os folcloristas. Ver, por exemplo, o precioso verbete sobre o bumba-meu-boi, em Camara Cascudo (1984). Interessante notar, como observou Travassos (1997), que Mário de Andrade se dá conta também da influência de poetas letrados e urbanos na conformação das danças, o que o desagrada e desconcerta, indo contra as premissas da autenticidade popular. Ver nota 4 das DD (1982, p. 71). Visto por um outro ângulo, esse afã de busca de origens remotas revela a permanência de certas formas culturais, cuja vida se situa num plano cultural, que se aproximam da idéia da "longa duração" (e de seus incertos caminhos) tão cara aos historiadores.

39 Ver, a esse respeito, Abreu (1998).

40 Esse ponto importante é indicado numa nota (Andrade, 1982, pp. 71-75).

41 Mário de Andrade elencou nesse vasto conjunto de influências o teatro religioso semi-popular ibérico, acomodado pelos jesuítas aos interesses da catequese no Brasil. Curioso notar, entretanto (sobretudo se posto lado a lado com sua ênfase na dramatização), que Mário de Andrade "tem a sensação" de que esse teatro é um fenômeno à parte, que se desenvolveu ao lado das danças dramáticas, mas sem influência direta sobre elas (1982, p. 30).

42 Oneida Alvarenga o auxilia nesse ponto do argumento, acrescentando em nota um trecho de "Reisados e romances". Na visão de Mário de Andrade, nos diz ela, os reisados seriam um caso de grande importância para o estudo do folclore. "São eles o fenômeno mais extraordinário de aproveitamento popular e conversão de forma, que já sofreram em qualquer país as poesias historiadas e contadas sejam em romances, baladas, gestas ou que nome tenham" (Andrade, 1982, p. 50).

43 Como, por exemplo, "O do Zé do Vale, aproveitado dum romance brasileiro do ciclo do cangaço" (Andrade, 1982, p. 51). Em alguns momentos do texto, essa idéia é mesmo a definidora dos reisados, que resultam "da adaptação dramático-coreográfica de um tema oriundo de romances medievais aqui chegados com a colonização e cantigas populares" (Idem, ibidem).

44 Ver também nas páginas 25 e 26 o tema da morte e da ressurreição que se impõe "em grande número das nossas danças dramáticas", não naquelas de origem mais nitidamente européia, como nas Cheganças. Esse tema surgiria sobretudo "nos bailados mais próximos das culturas primitivas, nos Congos de origem negra, nos Cabocolinhos de inspiração ameríndia, e nos Reisados e cordões de bichos de sobrevivência do culto animal, que se dá morte e ressurreição".

45 As famigeradas três raças presentes já no primeiro parágrafo do texto DD na suave ironia modernista "E se me fatiga bastante, pela sua precariedade contemporânea, afirmar que o povo brasileiro é formado das três correntes: portuguesa, africana e ameríndia, sempre é comovente verificar que apenas essas três bases étnicas o povo celebra secularmente em suas danças dramáticas" (Andrade, 1982, p. 23) - retornam, também, como que "sintetizadas" no Boi. Para Lopez, Mário de Andrade teria estabelecido, via Frazer, o culto na bagagem folclórica do colonizador, que no Brasil entraria em contato com o "espírito totêmico do índio" e, mais tarde, "receberá igual influência totêmica do negro" (1972, p. 130). Creio que Mário de Andrade realmente tinha alguma consciência da precariedade dessas idéias e, de fato, nunca se arriscou a sistematizá-las.

46 Belmont chamou atenção para a importância conceitual da noção de sobrevivência no avanço dos estudos antropológicos em fins do século XIX. Tal como proposta por Tylor e seus discípulos, essa noção "teorizava de modo bem sucedido a dupla exigência do distanciamento no tempo e no espaço, necessária para considerar sem temor a alteridade e a estranheza tanto dos povos primitivos quanto dos camponeses europeus" (1986, p. 262). Logo na segunda nota das DD, Mário de Andrade sofistica a idéia de sobrevivência puramente mecânica e só re- 
sidual, detendo-se no problema de "compreender a permanência de certas tradições de realidades extintas, na coletividade" (1982, p. 71). Seu pensamento se amplia e, embora se saiba de sua leitura de Formas elementares da vida religiosa de Durkheim, ele nunca realmente a incorporou. A vastidão simbólica de certos temas permitiria ao povo "O exercício permanente de certas práticas vitais”. Na sua comtemporaneidade, o boi já não representaria mais o animal tão historicamente básico da civilização nacional. Mas evocaria (de forma grata à "representação coletiva") as "dificuldades e lutas pra conquistar o alimento, bem como as práticas da vida familiar e coletiva [...] o tema não é mais uma idéia, mas toda uma ideologia. A sua força e vagueza lhe asseguram aceitação e permanência. É o jogo de sentido spenceriano, em que se exercita em brinquedo uma atividade vital [...]" (Idem, ibidem). Ainda assim, o estímulo "criativo" que gera a dança dramática é explicado pelo viés do evolucionismo intelectualista, derivando a ação vital de um pensamento inaugural.

47 Em pequena nota registrada no dia 9 de janeiro de 1929 no Rio Grande do Norte, no engenho Bom Jardim, de Antônio Bento, lemos: "Trabalho quase dia todo. De noite o "Boi" de Fontes veio dançar no engenho. A mais perfeita dança dramática que já vi na viagem. Artistas deliciosos de espontaneidade e espírito" (Andrade, 1976, p. 356). Na crônica do diário relativa a esse dia (Idem, pp. 271-272), Mário de Andrade descreve um engenho de banguê e o fabrico do açúcar. Embora outra anotação revele que, no dia seguinte, 10 de janeiro, ele tenha passado o dia trabalhando com os artistas desse boi, não há nenhuma elaboração acerca do assunto nas crônicas da viagem. Talvez o tema ficasse de alguma forma guardado para elaborações posteriores. De todo modo, vale observar que o encontro da "mais perfeita dança dramática da viagem toda" será imediatamente sucedido por outra "comoção formidável", a de seu encontro com o coqueiro Chico Antônio, ocorrido na noite do mesmo 10 de janeiro (Idem, p. 273). Mesmo o sentimento de "divinização" trazido por esse encontro carrega um amargor de perda: "E terei de ir para São Paulo e terei de escutar as temporadas líricas e as chiques dissonâncias dos modernos... Também Chico Antônio está se estragando... meio curvo, com os seus 27 anos esgotados na cachaça e noites inteiras a cantar..."(Idem, p. 277). Vale notar que Chico Antônio teve vida longa, tendo falecido em 1993. Ver a respeito o documentário de Eduardo Escorel, Chico Antônio: um herói com caráter (1983).
48 Luciana Carvalho (2003) lança questões novas para a compreensão da natureza das "comédias" e "matanças" do bumba-meu-boi maranhense.

49 A autora indica duas formas de lidar com a situação. Uma delas seria a interrogação sobre a natureza mesma do folclore como disciplina anteriormente autônoma. A segunda seria a indagação sobre a natureza do fato vivo que permanece sob a rubrica de "folclore" (Belmont, 1986, p. 260). Para a aboragem do primeiro ponto no Brasil, remeto novamente o leitor a Cavalcanti et al. (1992), Cavalcanti e Vilhena (1990) e, especialmente, a Vilhena (1997). Com relação ao segundo ponto, essa é exatamente a natureza do esforço aqui empreendido. A análise do bumba-meu-boi em Mário de Andrade busca desprender o fato vivo "brincadeira do boi" de todo um ativo conjunto de pressuposições e ilusões.

50 A autora refere-se especialmente à possibilidade de alcançar o passado oferecida pelos informantes mais idosos e à dimensão sincrônica da temporalidade presente nesses relatos.

\section{BIBLIOGRAFIA}

ABREU, Joana Cavalcanti. (2001), "Entre os símbolos e a vida: poesia, educação e folclore", in Margarida Souza Neves et al. (orgs.), Cecília Meireles: a poética da educação, Rio de Janeiro/São Paulo, Editora da PUC-Rio/Loyola, pp. 211-229.

ABREU, Martha. (1998), "Mello Moraes Filho: festas, tradições populares e identidade nacional", in S. Chaloub e L. M. Pereira (orgs), A bistória contada, Rio de Janeiro, Nova Fronteira, pp. 171-193.

ANDRADE, Mário. (1934a), "Danças dramáticas, introdução e primeira versão". Arquivo Mário de Andrade, IEB/USP, 27 pp.

(1934b), "Danças dramáticas, introdução e primeira versão". Arquivo Mário de Andrade, IEB/USP, 36 pp.

(1976), O turista aprendiz (estabelecimento de texto, introdução e notas de Telê Porto Ancona Lopez). São Paulo, Livraria Duas Cidades/Secretaria da Cultura, Ciência e Tecnologia. 
(1972), Ensaio sobre a música brasileira. São Paulo, Martins.

([1928] 1978), Macunaíma (o berói sem nenhum caráter). São Paulo, Livraria Martins Editora.

(1982), "As danças dramáticas do Brasil", in Danças dramáticas do Brasil (org. Oneida Alvarenga), São Paulo, Itatiaia/Instituto Nacional do Livro/Fundação Nacional Pró-Memória, 2 ed., tomo I, pp. 23-84.

(1982), Danças dramáticas do Brasil. (org. Oneida Alvarenga), São Paulo, Itatiaia/Instituto Nacional do Livro/Fundação Nacional Pró-Memória, 2 ed., tomos I, II e III.

(1993), Mário de Andrade. Poesias Completas (edição crítica de Diléa Zanotto Manfio). Belo Horizonte/Rio de Janeiro, Villa Rica.

(2000), Cartas de Mário de Andrade a Luis da Camara Cascudo (introdução e notas de Veríssimo de Melo). Belo Horizonte/Rio de Janeiro, Itatiaia.

(2002a), "Do Cabotinismo", in , O empalhador de passari-

nho, Belo Horizonte, Itatiaia (23-VII1939), pp. 81-85.

(2002b), "Do trágico", in

O empalhador de passarinho, Belo Horizonte, Itatiaia (10-IX-1939), pp. 113118.

BELMONT, Nicole. (1986), "Le folklore refoulé, ou les séductions de l'archaisme". L'Homme, XXVI (1-2): 259-268, jan.-jun.

BORBA FILHO, Hermilo. (1966), Apresentação do Bumba meu boi: o Boi misterioso de Afogados. Recife, Imprensa Universitária.

BUARQUE DE HOLLANDA, Heloisa. (1978), Macunaima: da literatura ao cinema. Rio de Janeiro, Livraria José Olimpio Ed./Embrafilme.
BYINGTON, Sílvia Ilg. (2000), Sentimentos modernistas: as cores do Brasil na correspondência entre Luís da Camara Cascudo e Mário de Andrade. Dissertação de mestrado, Rio de Janeiro, Depto. de História, PUC/RJ.

CAMARA CASCUDO, Luís da. (1984), "Bumbameu-boi", in Dicionário do folclore brasileiro, 5 ed., Belo Horizonte, Itatiaia.

CAVALCANTI, Maria Laura Viveiros de Castro. (2000), "O Boi-Bumbá de Parintins: breve história e etnografia da festa". Revista História, Ciência e Saúde: Visões da Amazônia, VI (suplemento especial nov.): 1019-1046, Rio de Janeiro, FioCruz.

. (2002), "Os sentidos no espetáculo". Revista de Antropologia, 45 (1): 37-89, São Paulo, Departamento de Antropologia, USP.

CAVALCANTI, M. L. V. de Castro; LINS E BARROS, Myriam; ARAÚJO, Silvana; MELLO E SOUZA, Marina \& VILHENA, Luis Rodolfo. (1992), "Os estudos de folclore no Brasil", in CNFCP - Centro Nacional de Folclore e Cultura Popular, Folclore e cuthra popular: as várias faces de um debate (série "Encontros e Estudos"), Rio de Janeiro, Funarte/CNFCP, pp. 101-112.

CAVAlCANTI, M. L. \& VILHENA, L. R. (1990), "Traçando fronteiras: Florestan Fernandes e a marginalização do folclore". Estudos Históricos, 5: 75-92, Rio de Janeiro, FGV.

DUARTE, Luiz Fernando Dias. (2003), “A pulsão romântica e as ciências humanas no Ocidente". Rio de Janeiro, 15 pp. (mimeo.).

ESCOREL, Eduardo. (1983), Chico Antônio: o berói com caráter. Documentário.

FERNANDES, Florestan. ([1946] 1989), "Mário de Andrade e o folclore brasileiro", in , O folclore em questão, São Paulo, Hucitec, pp. 147-168.

GEIGER, Amir. (1999), Uma antropologia sem métier: primitivismo e crítica cultural no 
modernismo brasileiro. Tese de doutorado, Rio de Janeiro, PPGAS/UFRJ.

GICO, Vânia de Vasconcelos. (2002), "Câmara Cascudo e Mário de Andrade: uma sedução epistolar". Revista do Patrimônio Histórico e Artístico Nacional-Mário de Andrade, 30: 110-127. Brasília, IPHAN/Minc.

GOMES, Ângela de Castro. (1998), "Nas malhas do feitiço". Estudos Históricos, 11 (21): 124, Rio de Janeiro.

GONÇALVES, José Reginaldo. (1997), A retórica da perda. Rio de Janeiro, Editora da UFRJ/Funarte.

CARVALHO, Luciana Gonçalves. (2003). "O desejo de Betinho e o decreto do presidente ou a questão da autoria no bumbameu-boi do Maranhão e as políticas para o patrimônio imaterial no Brasil", 15 pp., (mimeo.).

HOUAISS, Antônio. (2001). Dicionário Houaiss da lingua portuguesa. Rio de Janeiro, Objetiva.

LEACH, Edmund. (1980), "L'unité de l'homme: histoire d'une idée", in

L'unité de l'homme et autres essais, $\mathrm{Pa}$ ris, Gallimard, pp. 363-389.

LEIRIS, Michel. (2002), Espelho da tauromaquia. São Paulo, Cosac \& Naify.

LÉVI-STRAUSS, Claude. (1970), O pensamento selvagem. São Paulo, Companhia Editora Nacional/Edusp.

(1964), Mythologiques I. Paris, Plon. (1971), Mythologiques IV. Paris, Plon.

LOPEZ, , Telê Porto Ancona. (1972), Mário de Andrade: ramais e caminhos. São Paulo, Duas Cidades.

(2002), "O Boi em Mário de Andrade". Comunicação apresentada no XVI Moitará, Sociedade Brasileira de Psicologia Analítica, São Paulo, Campos de Jordão (mimeo.).

LOVEJOY, Arthur. (1965), The primitivism and related ideas in antiquity. Nova York, Oc- tagon Books.

MELLO E SOUZA, Gilda. (1979), O tupi e o alaúde. São Paulo, Duas Cidades.

MENDONÇA, Cecília. (2002), "O folclore nordestino e a busca do Brasil em Mário de Andrade". Trabalho apresentado na Jornada de Iniciação Científica, Rio de Janeiro, IFCS, UFRJ, nov.

MEYER, Marlyse. (1991), "O elemento fantástico numa forma de teatro popular brasileiro: o Bumba-meu-boi", in Pirineus, caiçaras... da Commedia dell'Arte ao Bumba-meu-boi, Campinas, Editora da Universidade Estadual de Campinas, pp. 55-70.

MICELI, Sergio. (2002), "Disciplina de amor". FOlha de S. Paulo (Caderno de Resenhas), 14 mar.

MERQUIOR, José Guilherme. (1981), "Macunaíma sem ufanismo", in — As idéias e as formas, Rio de Janeiro, Nova Fronteira, pp. 264-269.

MORAES, Eduardo Jardim de. (1978), A brasilidade modernista: sua dimensão filosófica. Rio de Janeiro, Graal.

(1983), A constituição da idéia de modernidade no modernismo brasileiro. Tese de doutorado, Rio de Janeiro, Deprtamento de Filosofia, IFCS/UFRJ.

(1992), "Modernismo e folclore", in CNFCP - Centro Nacional de Folclore e Cultura Popular, Folclore e cultura popular: as várias faces de um debate (série "Encontros e Estudos"), Rio de Janeiro, Funarte/CNFCP, pp. 75-78.

(1999), Limites do moderno: o pensamento estético de Mário de Andrade. Rio de Janeiro, Relume Dumará.

NEVES, Margarida de Souza. (1998), "Da maloca do Tietê ao Império do mato virgem Mário de Andrade: roteiros e descobrimentos", in Sidney Chalhoub (org.), A bistória contada, Rio de Janeiro, Nova Fronteira, pp. 265-300. 
ORTIZ, Renato. (s. d.), Românticos e folcloristas. São Paulo, Olho d'água, pp. 11-75.

PEIXOTO, Fernanda. (2002), "Mário e os primeiros tempos da USP". Revista do Patrimônio Histórico e Artístico Nacional Mário de Andrade, 30: 156-169, Brasília, IPHAN/Minc.

PEREIRA DE QUEIROZ, Maria Isaura. (1967), "O bumba-meu-boi, manifestação do teatro popular no Brasil". Revista do Instituto de Estudos Brasileiros, 2: 87-97, São Paulo, Ministério da Educação e Cultura, Departamento de Assuntos Culturais.

ROSENFELD, Anatol. (1973), "Mário e o cabotinismo", in Texto e contexto, São Paulo, Perspectiva/INL/MEC, pp. 185-200.

SANDRONI, Carlos. (1988), Mário contra Macunaíma: cultura e política em Mário de Andrade. Rio de Janeiro, Vértice/Iuperj.

(1992), "Mário de Andrade, antropófago", in CNFCP - Centro Nacional de Folclore e Cultura Popular, Folclore e cultura popular: as várias faces de um debate (série "Encontros e Estudos"), Rio de Janeiro, Funarte/CNFCP, pp. 79-83.

STOCKING JR., George W. (1989), "The ethnographic sensibility of the 1920s and the dualism of the anthropological tradition", in George W. Stocking Jr. (ed.), Romantic motives: essays on anthropological sensibility (History of anthropology, vol 6), Madison, The University of Wisconsin Press, pp. 208-279.

TODOROV, Tzevetan. (1996), "A crise romântica", in Teorias do símbolo, Campinas, Papirus, pp. 193-279.

TRAVASSOS, Elizabeth. (1997), Os mandarins milagrosos: arte e etnogafia em Mário de Andrade. Rio de Janeiro, Jorge Zahar.

(2002), "Mário e o folclore". Revista do Patrimônio Histórico e Artístico Nacional - Mário de Andrade, 30: 90-109, Brasília: IPHAN/Minc.
VILHENA, Luis Rodolfo da Paixão. (1997), Projeto e missão: o movimento folclórico brasileiro (1947-1964). Rio de Janeiro, FGV/Funarte.

WISNIK, José Miguel. (1979), "Dança dramática": poesia/música brasileira. Tese de doutorado, São Paulo, FFLCH/USP.

ZENGOTITA, Thomas de. (1989), "Speakers of being: romantic refusion and cultural anthropology", in George W. Stocking Jr. (ed.), Romantic motives: essays on anthropological sensibility (History of anthropology, vol 6), Madison, The University of Wisconsin Press, pp. 74-123. 


\section{CULTURA POPULAR E SENSI- BILIDADE ROMÂNTICA: AS DANÇAS DRAMÁTICAS DE MÁRIO DE ANDRADE}

Maria Laura Viveiros de Castro Cavalcanti

\section{Palavras-chave}

Mário de Andrade; Etnografia; Danças dramáticas;

Romantismo; Bumba-meu-boi.

Este texto examina a noção de danças dramáticas na obra de Mário de Andrade e investiga as razões da extrema valorização do bumbameu-boi por esse autor. Com base em uma perspectiva antropológica contemporânea, examinam-se as conexões existentes entre o uso da perspectiva etnográfica, a visão romântica da cultura popular e a busca de autenticidade na construção de formas estéticas pelo modernismo andradiano.

\section{POPULAR CULTURE AND ROMANTIC SENSIBILITY: THE DRAMATIC DANCES OF MÁRIO DE ANDRADE}

Maria Laura Viveiros de Castro Cavalcanti

\section{Keywords:}

Mário de Andrade; Ethnography; Dramatic dances; Romanticism; Bumba-meu-boi.

The text examines the notion of dramatic dances in the work of Mário de Andrade and investigates the reasons bumba-meu-boi was extremely valued by the author. It analyzes the connections found in the use of an ethnographic perspective, a romantic view on popular culture, and the pursuit of authenticity in constructing aesthetical forms by the andradiano modernism, based on a contemporary anthropological perspective.

\section{CULTURE POPULAIRE ET SENSIBILITÉ ROMANTIQUE : LES DANSES DRAMATIQUES DE MÁRIO DE ANDRADE}

Maria Laura Viveiros de Castro Cavalcanti

\section{Mots-clés}

Mário de Andrade;

Ethnographie; Danses dramatiques; Romantisme; Bumbameu-boi.

Ce texte examine la notion de danses dramatiques dans l'œuvre de Mário de Andrade et recherche les raisons de la valorisation extrême de la danse du bumba-meu-boi par cet auteur. Suivant une perspective anthropologique contemporaine, l'auteur examine les connexions existantes entre l'usage de la perspective ethnographique, la perception romantique de la culture populaire et la recherche de l'authenticité dans la construction de formes esthétiques par le modernisme de Mário de Andrade. 